\title{
Health-related quality of life questionnaires in lung cancer trials: a systematic literature review
}

\author{
Kathrin Damm ${ }^{1 *}$, Nicole Roeske ${ }^{1}$ and Christian Jacob ${ }^{2}$
}

\begin{abstract}
Background: Lung cancer is one of the leading causes of cancer deaths. Treatment goals are the relief of symptoms and the increase of overall survival. With the rising number of treatment alternatives, the need for comparable assessments of health-related quality of life (HRQoL) parameters grows. The aim of this paper was to identify and describe measurement instruments applied in lung cancer patients under drug therapy.

Methods: We conducted a systematic literature review at the beginning of 2011 using the electronic database Pubmed.

Results: A total of 43 studies were included in the review. About 17 different measurement instruments were identified, including 5 generic, 5 cancer-specific, 4 lung cancer-specific and 3 symptom-specific questionnaires. In 29 studies at least 2 instruments were used. In most cases these were cancer and lung cancer-specific ones. The most frequently used instruments are the EORTC QLQ-C30 and its lung cancer modules LC13 or LC17. Only 5 studies combined (lung) cancer-specific questionnaires with generic instruments.
\end{abstract}

Conclusions: The EORTC-C30 and EORTC-LC13 are the most frequently used health-related quality of life measurement instruments in pharmacological lung cancer trials.

Keywords: Lung cancer, Health-related quality of life, Questionnaires, Health economics, Utility measurement

\section{Review}

Introduction

Lung cancer is one of the most frequent cancers in Germany. With more than 47,000 new cases in 2006, lung cancer ranks third among malignant tumors; with a 5 -year survival rate of about 15\% [1]. Symptoms include cough, coughing up blood, shortness of breath, chronic lung inflammation, chest pain, weakness or loss of appetite. Due to a long term symptom-free course of the disease and non-specific complaints at first, lung cancer in contrast to other tumours is often diagnosed at an advanced stage. Therefore, treatment goals for these patients are symptom relief and an increased overall survival [2]. At the same time therapies that improve survival time are often accompanied by burdensome (toxic) side effects.

Because of the increasing number of therapy lines and treatment alternatives, the declining differences in clinical effectiveness and cost of drugs, the importance of consistent and comparable health-related quality of life (HRQoL)

\footnotetext{
* Correspondence: kd@ivbl.uni-hannover.de

${ }^{1}$ Center for Health Economics Research Hannover (CHERH), Leibniz University Hannover, Hannover, Germany

Full list of author information is available at the end of the article
}

parameters grows - both for medical and health economic evaluation. Up to today, their inclusion in clinical lung cancer trials is generally neglected [2-4].

The questionnaire-based measurement of HRQoL has become standard. To assess the HRQoL in patients with lung cancer, about 50 different instruments are available that directly address to the patient or apply to the practitioner [4]. In general, criteria used to distinguish the various instruments are the aggregated or disaggregated scores, ordinal measures or cardinal scales and the disease specificity (see Table 1) [5].

In addition to former research by Liu et al. [3], who reviewed and summarized HRQoL measures in kidney cancer, hepatocellular carcinoma, and leukemia, the aim of this systematic literature review is to investigate which questionnaires are applied in lung cancer patients treated with drugs. Using this approach, we examine whether the variety of possible lung cancer measurement instruments is also reflected by research practice.

\section{Methods}

Research and documentation were carried out in accordance with the guideline PRISMA (Preferred Reporting Items for 
Table 1 Classification of HRQoL-questionnaires

\begin{tabular}{|c|c|c|c|c|c|}
\hline \multicolumn{6}{|c|}{ Classification of HRQoL-questionnaires } \\
\hline \multicolumn{2}{|c|}{ Aggregation of results } & \multicolumn{2}{|c|}{ Disease specificity } & \multicolumn{2}{|c|}{ Scaling } \\
\hline $\begin{array}{l}\text { Separate measurement of } \\
\text { different dimensions of HRQOL }\end{array}$ & $\begin{array}{l}\text { Aggregation to } \\
\text { an index }\end{array}$ & $\begin{array}{l}\text { Comparison within } \\
\text { a group of patients }\end{array}$ & $\begin{array}{c}\text { Comparison between } \\
\text { patient groups }\end{array}$ & $\begin{array}{l}\text { Determining a } \\
\text { rank order }\end{array}$ & $\begin{array}{l}\text { Determining relative } \\
\text { distances }\end{array}$ \\
\hline $\begin{array}{l}\text { Particularly suitable for } \\
\text { medical purposes }\end{array}$ & $\begin{array}{l}\text { Particularly suitable for } \\
\text { economic purposes }\end{array}$ & $\begin{array}{l}\text { Particularly suitable } \\
\text { for medical purposes }\end{array}$ & $\begin{array}{l}\text { Particularly suitable for } \\
\text { economic purposes }\end{array}$ & $\begin{array}{l}\text { Particularly suitable } \\
\text { for medical purposes }\end{array}$ & $\begin{array}{l}\text { Particularly suitable for } \\
\text { economic purposes }\end{array}$ \\
\hline
\end{tabular}

Source: Based on Schöffski O (2007) [5]

Systematic Reviews and Meta-Analyses) [6]. We searched the database PubMed combining the following search terms: "Biological Therapy" (MeSH), "Chemicals and Drugs Category” (MeSH), "Drug Therapy” (MeSH), "Individualized Medicine" (MeSH), "Lung Neoplasms" (MeSH), "Outcome and Process Assessment (Health Care)" (MeSH Major Topic), "Quality of Life" (MeSH Major Topic), "Symptom Palliation" (Free text search, Major Topic). The quality of life associated key words were defined as major topic, to exclude articles that deal with the issue only as a secondary aspect. In addition, a manual search was carried out. In order to focus on current publications, the present review includes literature published in English and German language between 2001 and 2011. Titles, abstracts and full-texts of the identified studies were reviewed independently by three researchers. Exclusion criteria are documented in Figure 1 . The identified studies were analyzed concerning the HRQoL results and used questionnaires.

\section{Results}

A total of 43 studies on the HRQoL measurement in lung cancer patients treated with drugs were identified (see Figure 1). The language restriction led only to small deviations from the overall number of identified studies.

Most of the identified literature presents results of phase III clinical trials (see Table 2). In 27 studies HRQoL is a primary endpoint. The majority of studies $(n=38)$ includes patients with non-small cell lung cancer (NSCLC), mainly

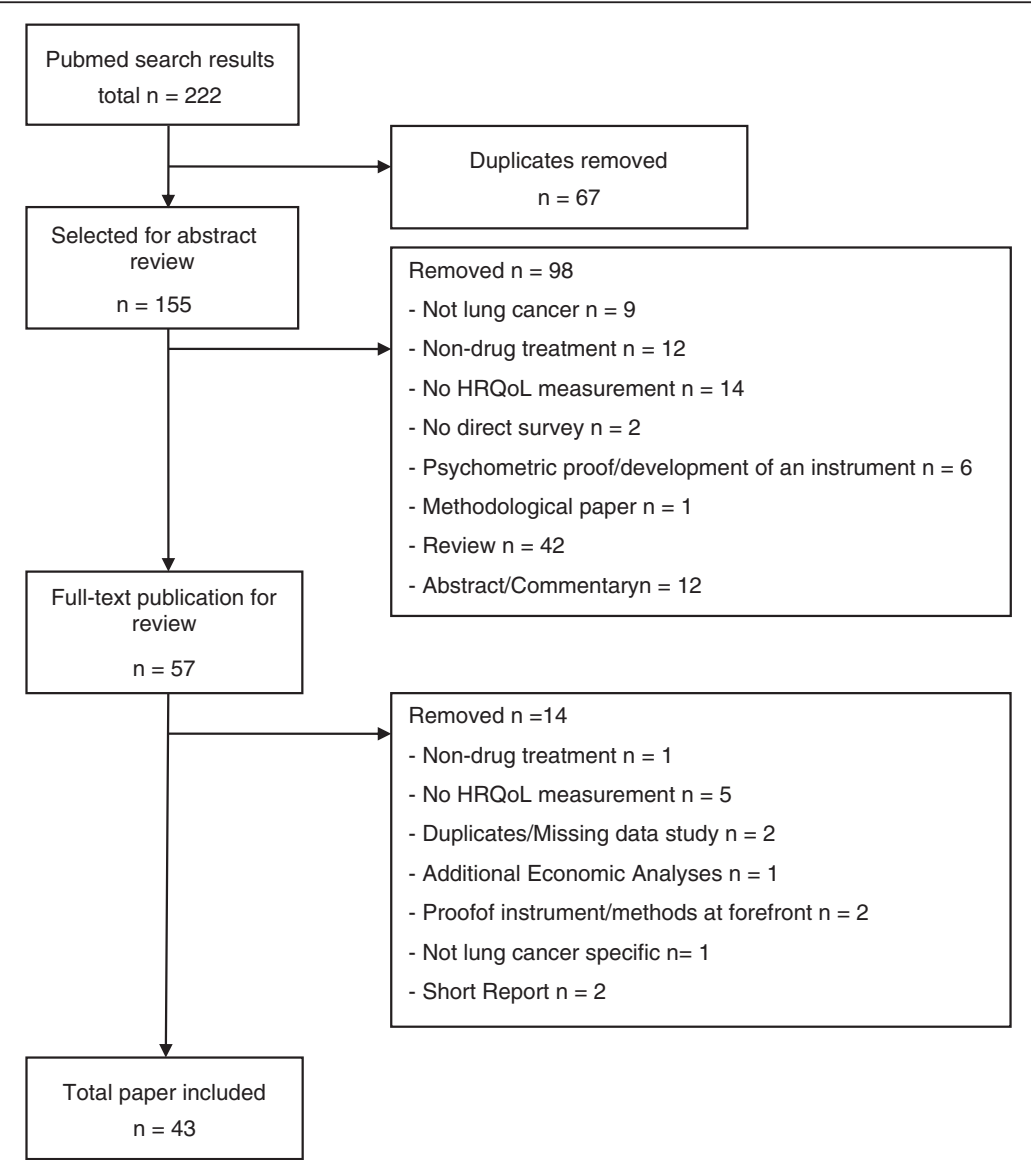

Figure 1 Flow chart of study selection. 
Table 2 Identified literature overview

\begin{tabular}{|c|c|c|c|c|c|}
\hline Author (Year) & $\begin{array}{l}\text { Study, Phase } \\
\text { tumor type stadium }\end{array}$ & Treatment outline & $\begin{array}{l}\text { HRQoL } \\
\text { endpoints }\end{array}$ & QoL outcome & QoL instruments \\
\hline $\begin{array}{l}\text { Agteresch HJ } \\
\text { et al. (2002) [7] }\end{array}$ & Clinical trial NSCLC IIIB/IV & $\begin{array}{l}\text { Adenosine 5'-Triphosphate } \\
\text { (ATP) vs. non }\end{array}$ & secondary & $\begin{array}{l}\text { No change in appetite and body comparison } \\
\text { in the ATP group. Control group lost weight } \\
\text { and appetite. }\end{array}$ & $\begin{array}{l}\text { Rotterdam Symptom } \\
\text { Checklist (RSCL) }\end{array}$ \\
\hline $\begin{array}{l}\text { Baka S et al. } \\
\text { (2005) [8] }\end{array}$ & Clinical trial, II NSCLC IIIB/IV & $\begin{array}{l}\text { Comparison of two different treatment } \\
\text { schedules for Gemcitabine }\end{array}$ & primary & $\begin{array}{l}\text { Significant improvement in performance from } \\
\text { baseline, no sign. difference between } \\
\text { treatment schedules. }\end{array}$ & $\begin{array}{l}\text { Subset Scale from the } \\
\text { EORTC QLQ-C30 and LC13, } \\
\text { Karnofsky performance scale }\end{array}$ \\
\hline $\begin{array}{l}\text { Belani C et al. } \\
\text { (2006) [9] }\end{array}$ & $\begin{array}{l}\text { Clinical trial, III NSCLC IIIB/ } \\
\text { IV }\end{array}$ & $\begin{array}{l}\text { Comparison of two Docetaxel-platinum } \\
\text { regimens with Vinorelbine/Cisplatin }\end{array}$ & primary & $\begin{array}{l}\text { Patients treated with Docetaxel-containing } \\
\text { regimen had better QoL and relieved symptoms. }\end{array}$ & LCSS, EQ-5D \\
\hline $\begin{array}{l}\text { Bezjak A et al. } \\
\text { (2008) [10] }\end{array}$ & Clinical trial, III NSCLC IB/II & $\begin{array}{c}\text { Adjuvant chemotherapy } \\
\text { (Cisplatin and Vinorelbine vs. non) }\end{array}$ & secondary & $\begin{array}{c}\text { After chemotherapy QoL returned to baseline } \\
\text { by } 9 \text { months compared to } 3 \text { months in the } \\
\text { control group. }\end{array}$ & EORTC QLQ-C30 \\
\hline $\begin{array}{l}\text { Bezjak A et al. } \\
(2006)[11]\end{array}$ & $\begin{array}{l}\text { Clinical trial, III NSCLC } \\
\text { advanced }\end{array}$ & $\begin{array}{l}\text { Erlotinib vs. placebo after } \\
\text { prior chemotherapy }\end{array}$ & secondary & $\begin{array}{l}\text { Sign. Improvement in physical and global QoL, } \\
\text { dypnea, cough, pain, emotional functioning, } \\
\text { deterioration in sore mouth and hairloss } \\
\text { compared to baseline. }\end{array}$ & EORTC QLQ-C30,-LC13 \\
\hline $\begin{array}{l}\text { Bianco V et al. } \\
\text { (2001) [12] }\end{array}$ & Clinical trial NSCLC IIIB/IV & $\begin{array}{l}\text { Gemcitabine as single agent therapy in } \\
\text { advanced NSCLC in elderly patients }(>65)\end{array}$ & primary & Improvement in QoL, reduction of symptoms. & $\begin{array}{l}\text { Spitzer-Index, Instrumental } \\
\text { Activities of Daily Living Scale } \\
\text { (IADL), EORTC QLQ-C30,-LC13 }\end{array}$ \\
\hline $\begin{array}{l}\text { Booton R et al. } \\
\text { (2006) [13] }\end{array}$ & Clinical trial, III NSCLC III/IV & $\begin{array}{l}\text { Docetaxel/Carboplatin vs. Mitomycin } \\
\text { C/Cisplatin/Ninblastine vs. } \\
\text { Ifosfamide/Cisplatin }\end{array}$ & secondary & No superiority of one regimen. & $\begin{array}{c}\text { Hospital Anxiety and Depression } \\
\text { Scale (HADS), EORTC } \\
\text { QLQ-C30,-LC13 }\end{array}$ \\
\hline $\begin{array}{l}\text { Bozcuk H et al. } \\
\text { (2006) }[14]\end{array}$ & Clinical trial NSCLC IIIB/IV & $\begin{array}{l}\text { Examining determinants of a QoL } \\
\text { improvement with chemotherapy in } \\
\text { patients with advanced NSCLC. }\end{array}$ & primary & $\begin{array}{l}\text { Age, baseline QoL and chemotherapy } \\
\text { administration influence the degree of } \\
\text { change in QoL. }\end{array}$ & EORTC QLQ-C30 \\
\hline $\begin{array}{l}\text { Brown J et al. } \\
\text { (2005) [15] }\end{array}$ & Clinical trial NSCLC IV & $\begin{array}{l}\text { Supportive care with vs. without } \\
\text { additional chemotherapy }\end{array}$ & primary & No sign. difference in QoL. & EORTC QLQ-C30,-LC17 \\
\hline $\begin{array}{l}\text { Cella D et al. } \\
\text { (2005) [16] }\end{array}$ & $\begin{array}{l}\text { Clinical trial, II NSCLC } \\
\text { advanced }\end{array}$ & $\begin{array}{l}\text { Comparison of two different treatment } \\
\text { dosages Gefitinib in heavily } \\
\text { pretreated patients }\end{array}$ & $\begin{array}{l}\text { primary and } \\
\text { secondary }\end{array}$ & $\begin{array}{l}\text { QoL improvements were correlated with } \\
\text { tumor response. }\end{array}$ & FACT-L \\
\hline $\begin{array}{l}\text { Chen M.-L. } \\
\text { (2008) [17] }\end{array}$ & $\begin{array}{l}\text { Clinical trial NSCLC } \\
\quad \text { IIIB/VV, SCLC }\end{array}$ & $\begin{array}{l}\text { Examining the impact of sleep } \\
\text { disturbance of lung cancer patients } \\
\text { undergoing chemotherapy on their QoL }\end{array}$ & primary & $\begin{array}{l}\text { Sign. impact on the cognitive function } \\
\text { and functional status. }\end{array}$ & $\begin{array}{l}\text { HADS, Pittsburgh Sleep Quality } \\
\text { Index (PSQI), Brief Pain Inventory } \\
\text { (BPI), EORTC QLQ-C30,-LC13 }\end{array}$ \\
\hline $\begin{array}{l}\text { Dancey J et al. } \\
\text { (2004) [18] }\end{array}$ & $\begin{array}{l}\text { Clinical trial, III NSCLC IIIB/ } \\
\text { IV }\end{array}$ & $\begin{array}{l}\text { Docetaxel second-line vs. Best } \\
\text { Supportive Care (BSC) }\end{array}$ & secondary & $\begin{array}{l}\text { A trend towards less deterioration in QoL } \\
\text { compared to BSC }\end{array}$ & LCSS EORTC QLQ-C30,-LC13 \\
\hline $\begin{array}{l}\text { de Marinis F } \\
\text { et al. (2008) [19] }\end{array}$ & Clinical trial, III NSCLC III/IV & Pemetrexed vs. Docetaxel & secondary & $\begin{array}{l}\text { Positive response on chemotherapy } \\
\text { correlates with symptom improvement. }\end{array}$ & LCSS \\
\hline $\begin{array}{l}\text { Gelibter A et al. } \\
(2005)[20]\end{array}$ & $\begin{array}{l}\text { "Compassionate-Use" } \\
\text { NSCLC III/IV }\end{array}$ & Gefitinib & primary & $\begin{array}{l}\text { Improvements in fatigue, insomnia, and pain, } \\
\text { deterioration in sore mouth, chest-pain, diarrhea. }\end{array}$ & EORTC QLQ-C30,-LC13 \\
\hline $\begin{array}{l}\text { Gridelli C et al. } \\
\text { (2003) [21] }\end{array}$ & $\begin{array}{l}\text { Clinical trial, III NSCLC IIIB/ } \\
\text { IV }\end{array}$ & $\begin{array}{l}\text { Gemcitabine/Vinorelbine vs. Gemcitabine/ } \\
\text { Cisplatin vs. Vinorelbine/Cisplatin }\end{array}$ & primary & $\begin{array}{l}\text { Global QoL is not improved with } \\
\text { GemcitabineNinorelbine. }\end{array}$ & EORTC QLQ-C30,-LC13 \\
\hline $\begin{array}{l}\text { Grønberg BH et al. } \\
(2009)[22]\end{array}$ & Clinical trial, III NSCLC IIIB/IV & $\begin{array}{l}\text { First-line Pemetrexed/Carboplatin } \\
\text { vs. Gemcitabine/Carboplatin }\end{array}$ & primary & $\begin{array}{l}\text { Pemetrexed/Carboplatin provides similar } \\
\text { HRQoL with less need for supportive care. }\end{array}$ & EORTC QLQ-C30,-LC13 \\
\hline
\end{tabular}


Table 2 Identified literature overview (Continued)

\begin{tabular}{|c|c|c|c|c|c|}
\hline $\begin{array}{l}\text { Helbekkmo N et al. } \\
\text { (2009) [23] }\end{array}$ & Clinical trial, III NSCLC IIIB/IV & $\begin{array}{l}\text { Carboplatin Chatelut AUCNinorelbine } \\
\text { or Carboplatin/Gemcitabine in } \\
\text { patients with a performance status (PS) } \\
2 \text { compared to patients with PS } 0 / 1\end{array}$ & primary & $\begin{array}{l}\text { PS } 2 \text { patients had a more profound } \\
\text { improvement of global HRQoL. }\end{array}$ & EORTC QLQ-C30,-LC13 \\
\hline $\begin{array}{l}\text { Hensing TA et al. } \\
\text { (2003) }[24]\end{array}$ & Clinical trial, III NSCLC IIIB/IV & $\begin{array}{l}4 \text { cycles of Carboplatin/Paclitaxel or } \\
\text { until disease progression in patients } \\
\text { younger than age } 70 \text { compared to } \\
\text { those aged } 70 \text { years and older }\end{array}$ & primary & No difference in QoL outcomes. & FACT-L \\
\hline $\begin{array}{l}\text { LeCaer H et al. } \\
\text { (2005) }[25]\end{array}$ & Clinical trial, II NSCLC IIIB/IV & Docetaxel monotherapy in elderly patients & primary & QoL remained stable during treatment. & $\begin{array}{l}\text { Spitzer-Index EORTC } \\
\text { QLQ-C30,-LC13 }\end{array}$ \\
\hline $\begin{array}{l}\text { Leighl NB et al. } \\
\text { (2005) [26] }\end{array}$ & $\begin{array}{l}\text { Clinical trial, III NSCLC IIIB/ } \\
\text { IV }\end{array}$ & $\begin{array}{l}\text { Paclitaxel/Carboplatin with or } \\
\text { without BMS-275291 }\end{array}$ & secondary & No detailed results presented. & EORTC QLQ-C30,-LC13 \\
\hline $\begin{array}{l}\text { Lilenbaum R et al. } \\
\text { (2007) [27] }\end{array}$ & Clinical trial, II NSCLC IIIB/IV & $\begin{array}{l}\text { Erlotinib vs. Paclitaxel/Carboplatin in } \\
\text { patients with a performance status (PS) of } 2\end{array}$ & secondary & No sign. differences. & EORTC QLQ-LC13 \\
\hline $\begin{array}{l}\text { Maione P et al. } \\
\text { (2005) [28] }\end{array}$ & $\begin{array}{l}\text { Clinical trial, III NSCLC IIIB/ } \\
\text { IV }\end{array}$ & $\begin{array}{l}\text { The prediction of pretreated QoL on the } \\
\text { survival of elderly NSCLC patients } \\
\text { treated with chemotherapy }\end{array}$ & primary & $\begin{array}{l}\text { Pretreatments global QoL has a sign. prognostic } \\
\text { value for survival of elderly patients with } \\
\text { advanced NSCLC treated with chemotherapy. }\end{array}$ & EORTC QLQ-C30,-LC13 \\
\hline $\begin{array}{l}\text { McQuellon R P } \\
\text { et al. (2002) [29] }\end{array}$ & $\begin{array}{l}\text { Clinical trial, III NSCLC, } \\
\text { SCLC }\end{array}$ & $\begin{array}{l}\text { Megestrol Acetate vs. placebo in patients } \\
\text { undergoing radiation therapy }\end{array}$ & primary & No sign. difference in overall QoL. & FACT-General, FACT-L \\
\hline $\begin{array}{l}\text { Mohan A et al. } \\
\text { (2008) [30] }\end{array}$ & QoL-study NSCLC III/IV & Cisplatin/Etoposide & primary & $\begin{array}{l}\text { Sign. improvement in cough, shortness of breath, } \\
\text { pain but not in QoL. }\end{array}$ & WHOQOL-BREF, Hindi \\
\hline $\begin{array}{l}\text { Moinpour CM } \\
\text { et al. (2002) [31] }\end{array}$ & $\begin{array}{l}\text { Clinical trial, III NSCLC IIIB/ } \\
\text { IV }\end{array}$ & Cisplatin/Vinorelbine vs. Carboplatin/Paclitaxel & secondary & No sign. difference in QoL. & FACT-L \\
\hline $\begin{array}{l}\text { Morita S et al. } \\
\text { (2003) [32] }\end{array}$ & $\begin{array}{l}\text { Clinical trial, III NSCLC IIIB/ } \\
\text { IV }\end{array}$ & $\begin{array}{c}\text { Cisplatin/Irinotecan vs. Cisplatin/Vindesine } \\
\text { vs. Irinotecan }\end{array}$ & secondary & $\begin{array}{l}\text { Clinical parameters have a sign. effect on QoL } \\
\text { in patients undergoing chemotherapy. }\end{array}$ & $\begin{array}{l}\text { QoL questionnaire for cancer } \\
\text { patients treated with } \\
\text { anti-cancer drugs (QOL-ACD) }\end{array}$ \\
\hline $\begin{array}{l}\text { Movsas B et al. } \\
(2005)[33]\end{array}$ & Clinical trial NSCLC II/IIA/B & $\begin{array}{l}\text { Paclitaxel/Carboplatin with or } \\
\text { without Amifostine }\end{array}$ & secondary & QoL was not sign. different between the arms. & EORTC QLQ-C30,-LC13 \\
\hline $\begin{array}{l}\text { Mu XL et al. } \\
\text { (2004) [34] }\end{array}$ & $\begin{array}{l}\text { "Compassionate-Use" } \\
\text { NSCLC III/IV }\end{array}$ & Gefitinib & primary & Symptom relief and improvement in QoL. & EORTC QLQ-C30,-LC13 \\
\hline $\begin{array}{l}\text { Natale RB } \\
(2004)[35]\end{array}$ & $\begin{array}{l}\text { Clinical trial, II NSCLC } \\
\text { advanced }\end{array}$ & Different treatment dosages Gefitinib & secondary & Improvements in symptoms and QoL. & FACT-L \\
\hline $\begin{array}{l}\text { O'Brian MER et al. } \\
\text { (2006) [36] }\end{array}$ & Clinical trialSCLC & $\begin{array}{l}\text { Best Supportive Care with or without } \\
\text { Topotecan in patients with relapsed SCLC }\end{array}$ & secondary & $\begin{array}{l}\text { Slower QoL deterioration and greater } \\
\text { symptom control. }\end{array}$ & $\begin{array}{l}\text { Patient self assessment similar } \\
\text { to the LCSS, EQ-5D }\end{array}$ \\
\hline $\begin{array}{l}\text { Paccagnella A } \\
\text { et al. (2004) [37] }\end{array}$ & $\begin{array}{l}\text { Clinical trial, III NSCLC IIIB/ } \\
\text { IV }\end{array}$ & $\begin{array}{l}\text { Mitomycin/Vinblastine/Cisplatin vs. } \\
\text { Mitomycin/Vinblastine/Carboplatin }\end{array}$ & primary & $\begin{array}{l}\text { Spitzer's questionnaire showed an improved } \\
\text { QoL index for Carboplatin. }\end{array}$ & $\begin{array}{l}\text { Spitzer-Index, EORTC } \\
\text { QLQ-C30,-LC13 }\end{array}$ \\
\hline $\begin{array}{l}\text { Pijls-Johannesma } \\
\text { M et al. (2009) [38] }\end{array}$ & $\begin{array}{l}\text { QoL-study NSCLC I - III, } \\
\text { SCLC }\end{array}$ & Radiotherapy with or without chemotherapy & primary & $\begin{array}{l}\text { Overall QoL increases back to baseline within } \\
\qquad 3 \text { months. }\end{array}$ & EORTC QLQ-C30,-LC13 \\
\hline $\begin{array}{l}\text { Reck M et al. } \\
\text { (2006) [39] }\end{array}$ & Clinical trial, III SCLC & $\begin{array}{l}\text { Paclitaxel/Carboplatin/Etoposide phosphate vs. } \\
\text { Carboplatin/Etoposide phosphate/vincristine }\end{array}$ & primary & $\begin{array}{l}\text { Paclitaxel-containing regimen sign. improved } \\
\text { QoL parameters like global overall QoL. }\end{array}$ & EORTC QLQ-C30 \\
\hline \multirow[t]{2}{*}{$\begin{array}{l}\text { Sarna L et al. } \\
\text { (2008) [40] }\end{array}$} & Clinical trial, III NSCLC I/III & $\begin{array}{l}\text { Paclitaxel/Carboplatin with or without } \\
\text { Amifostin }\end{array}$ & primary & QoL was not sign. different between the arms. & EORTC QLQ-C30,-LC13 \\
\hline & Clinical trial, III NSCLC III & & primary & & EORTC QLQ-C30,-LC13 \\
\hline
\end{tabular}


Table 2 Identified literature overview (Continued)

\begin{tabular}{|c|c|c|c|c|c|}
\hline $\begin{array}{l}\text { Schumacher A et al. } \\
\text { (2003) [41] }\end{array}$ & & $\begin{array}{c}\text { Cisplatin/Etoposide followed by either surgery } \\
\text { before radiotherapy or radio-chemotherapy } \\
\text { before surgery }\end{array}$ & & $\begin{array}{l}\text { On QoL no sign. effect was found in or } \\
\text { between the two treatments. }\end{array}$ & \\
\hline $\begin{array}{l}\text { Sekine I et al. } \\
\text { (2009) [42] }\end{array}$ & $\begin{array}{l}\text { Clinical trial, III NSCLC IIIB/ } \\
\text { IV }\end{array}$ & Gefitinib vs. Docetaxel & secondary & $\begin{array}{l}\text { Gefitinib improved aspects of QoL } \\
\text { over Docetaxel. }\end{array}$ & FACT-L \\
\hline $\begin{array}{l}\text { Sirisinha T et al. } \\
(2005)[43]\end{array}$ & N/A NSCLC II-IV & $\begin{array}{l}\text { Docetaxel after failure with platinum-based } \\
\text { chemotherapy }\end{array}$ & secondary & No negative impact on overall QoL. & FACT-L \\
\hline $\begin{array}{l}\text { Thatcher } \mathbf{N} \\
\text { et al. (2005) [44] }\end{array}$ & Clinical trial SCLC & $\begin{array}{l}\text { Ifosfamide/Carboplatin/Etoposid/Vincristine vs. } \\
\text { standard chemotherapy }\end{array}$ & primary & No sign. differences regarding QoL. & $\begin{array}{l}\text { Rotterdam Symptom Checklist, } \\
\text { HADS, EORTC QLQ-C30,-LC13 }\end{array}$ \\
\hline $\begin{array}{l}\text { Tian JH et al. } \\
\text { (2010) [45] }\end{array}$ & Clinical trial NSCLC IIIB/IV & $\begin{array}{l}\text { Chemotherapy vs. "Feiji Recipe" vs. } \\
\text { Chemotherapy/"Feiji Recipe" }\end{array}$ & primary & $\begin{array}{l}\text { "Feiji Recipe" alone or in combination } \\
\text { might partially improve QoL. }\end{array}$ & EORTC QLQ-C30 \\
\hline $\begin{array}{l}\text { Vilmar A et al. } \\
\text { (2010) [46] }\end{array}$ & Clinical trial, III NSCLC III/IV & $\begin{array}{l}\text { Chemotherapy; Determination of } \\
\text { biomarker ERCC1 }\end{array}$ & primary & $\begin{array}{l}\text { QoL deteriorated sign. among } \\
\text { survival-favourable ERCC1-neg. patients }\end{array}$ & EORTC QLQ-C30,-LC13 \\
\hline $\begin{array}{l}\text { von Plessen C } \\
\text { et al. (2006) [47] }\end{array}$ & Clinical trial NSCLC IIIB/IV & $\begin{array}{c}\text { Optimal duration of palliative Carboplatin } \\
\text { with Vinorelbine treatment }\end{array}$ & primary & No sign. differences between the arms. & EORTC QLQ-C30,-LC13 \\
\hline $\begin{array}{l}\text { Wu WY et al. } \\
\text { (2006) [48] }\end{array}$ & QoL-study NSCLC IIIB/IV & $\begin{array}{l}\text { Gemcitabine/Cisplatin with or without } \\
\text { Shenfu Injektion }\end{array}$ & primary & $\begin{array}{l}\text { Shengfu Injektion could improve QoL in } \\
\text { patients with Gemcitabine/Cisplatin treatment. }\end{array}$ & $\begin{array}{c}\text { Functional Living } \\
\text { Index-Cancer, EORTC QLQ-C30 }\end{array}$ \\
\hline $\begin{array}{l}\text { Zhang XT et al. } \\
(2005)[49]\end{array}$ & $\begin{array}{l}\text { "Compassionate-Use" } \\
\text { NSCLC III/IV }\end{array}$ & Gefitinib & primary & Symptom relief and improvement in QoL. & EORTC QLQ-C30,-LC13 \\
\hline
\end{tabular}

(2005) [49] NSCLC III/

Gefitinib

\author{
primary
}

EORTC QLQ -C30 = European Organization for Research and Treatment of Cancer Quality of Life Questionnaire-Core (30 Items); EORTC QLQ-LC13 = EORTC QLQ-Lung Cancer (13 Items); EQ-5D = EuroQol-5 Dimensions; FACT-G = Functional Assessment of Cancer Therapy-General; FACT-L = FACT-Lung; HADS = Hospital Anxiety and Depression Scale; LCSS = Lung Cancer Symptom Scale; NSCLC = Non-Small Cell Lung Cancer; $\mathrm{QoL}=$ Quality of Life, SCLC = Small Cell Lung Cancer; sign.= significant; WHOQOL = World Health Organization Quality of Life assessment instrument. 
in stages III/IV. Two studies include patients with small cell lung cancer (SCLC) in all stages. In three studies both NSCLC and SCLC patients entered. Mainly platinumbased drug combinations are trialed. Eight studies investigate EGFR inhibitors: 6 studies examine the effect of gefitinib, 2 the effect of erlotinib.

\section{Identified health-related quality of life (HRQoL) questionnaires}

Overall, 17 different measurement instruments were identified within the included studies (see Figure 2). Five of them are generic, such as the EQ-5D of the EuroQol group or the Spitzer Quality of Life Index. Another 5 instruments are cancer-specific, like the general quality of life questionnaires of the European Organization for Research and Treatment of Cancer (EORTC QLQ-C30) or the FACT-G (Functional Assessment of Cancer Therapy-General) questionnaire. Four instruments are lung cancer-specific, like the lung cancer modules of the EORTC and the FACT-L (Lung) questionnaire as well as the Lung Cancer Symptom Scale (LCSS). The remaining 3 questionnaires are symptom-specific, such as the Hospital
Anxiety and Depression Scale (HADS) or the Brief Pain Index (BPI).

The most frequently used instrument is the EORTC QLQ-C30 ( $n=29)$, a general questionnaire designed for (self- or interviewer administration) use in cancer patient populations [50]. This 30-item multi-dimensional questionnaire is available in over 60 languages and contains 4 domains (functional and symptom scales, global quality of life, and single items) requested by 4-point Likert or visual analogue scales. Its lung cancer specific module LC13 (13 additional items) is also used widely.

The FACT questionnaires are less frequently used $(n=8)$. Here, the FACT-G (General) contains 27 multi-dimensional items (physical, emotional, social and functional well-being) scored on 4-point scales [51], available in more than 50 languages. The lung cancer questionnaire (FACT-L) is a combination of the FACT-G and disease specific items (in total 37). Further information about the questionnaires as well as comparisons of possible instruments for lung cancer patients can e.g. be found on PROQOLID [52], and in Liu et al.[3], Camps et al.[4] or Damm et al. [53].

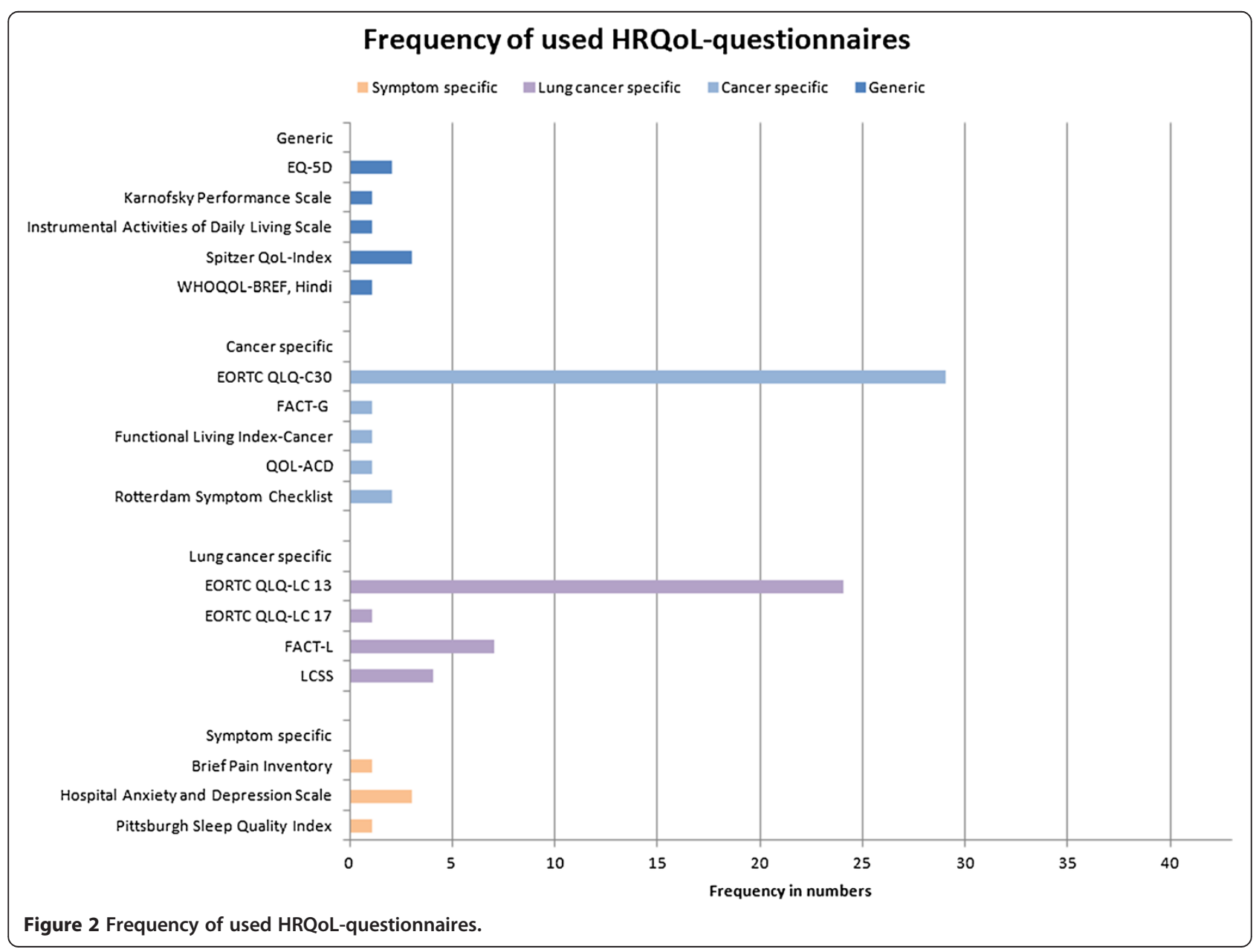


In 29 of our identified studies (67\%) at least two instruments were used, mostly cancer and lung cancer-specific ones (see Table 2). In 23 studies (53\%) the EORTC QLQC30 in conjunction with the LC13 module was used. Five studies combined disease-specific (cancer or lung cancer) questionnaires with generic instruments; two times the EQ-5D was applied.

\section{Content-related results of the identified literature}

Because of the different study populations and treatment regimes it is not possible to compare all the different studies in terms of HRQoL (see Table 2). However we tried to arrange some groups of HRQoL findings.

A majority of the included trials comparing various agent regimes shows no significant differences between treatment arms $[13,15,21,29,31,41,44,47]$. Another group of studies report cautious assumptions of HRQoL improvements [18,22,37]. Solely, Belani et al. and Reck et al. could show HRQoL-regarded superiority for paclitaxel or docetaxel containing regimes compared to vincristine or vinorelbine/cisplatin $[9,39]$.

With regard to the EGFR inhibitors Gelibter et al., $\mathrm{Mu}$ et al., and Zhang et al. all demonstrated symptom relief and improvement in HRQoL by the compassionate use of gefitinib in highly advanced NSCLC patients $[20,34,49]$. Cella et al. and Natale et al. reported on HRQoL improvements after the administration of gefitinib, compared to baseline in heavily pretreated patients and the correlation of these improvements to the tumour response [16,35].

In terms of erlotinib, Lilenbaum et al. could not show significant improvements in progression-free survival, median survival, and HRQoL in comparison to standard chemotherapy [27]. Bezjak et al. showed significant improvements in HRQoL, if erlotinib was given as second line treatment after chemotherapy [11].

Three studies investigated the application of cytostatic agents in elderly patients. Bianco et al. showed improvements in HRQoL for gemcitabine as a single agent therapy [12], Hensing et al. demonstrated that the application of carboplatin/paclitaxel has no significantly different impact on HRQoL between younger ( $<70$ years) and elderly patients [24]. LeCaer et al. showed stable HRQoL values during docetaxel monotherapy [25].

Movsas et al. and Sarna et al. reported no significant HRQoL differences between treatment regimes in combination with or without amifostine $[33,40]$.

A last group of studies showed influences on HRQoL values, e.g. age and baseline quality of life (QoL) [Bozcuk et al.], the cognitive function [Chen], as well as clinical parameters Morita et al. [14,17,32].

\section{Discussion}

The present study continues the work of previous reviews like the one of Liu et al. for the indication of lung cancer [3].

HRQoL measurement obtains a twofold meaning in the field of lung cancer medication. This is due to the often severe (toxic) therapeutic side effects, but also because of the high demand for symptom palliation. However, the measurement of HRQoL in respective trials is still not consistent and barely comparable [2-4].

By far the most frequently used questionnaire is the EORTC QLQ-C30 in conjunction with the lung cancerspecific module LC13. In comparison, even other lung cancer specific instruments like the FACT-L and the lung cancer symptom scale (LCSS) are only used in relatively few studies [4]. The same applies to the generic instruments. Especially the EQ-5D, which is relevant for health economic evaluations, is rarely used. However, it turns out that, besides the dominant EORTC instruments, a broad portfolio of other questionnaires is applied in different varieties and combinations. This also includes highly sensitive symptom-specific questionnaires. The comparability of these study results thereby is restricted.

A comparison with further literature shows that our results are e.g. in line with Liu et al. and also with Salvo et al. [3,54]. The latter conducted a literature review, published in 2009, searching for quality of life measurement instruments in cancer patients receiving palliative radiotherapy for symptomatic lung cancer. The authors also concluded that EORTC QLQ-C30 was the most commonly used questionnaire (in 13 of 20 trials). Of those 13 studies, 8 also used the LC13 module. The FACT-L was used in only 2 of the included 20 trials. Salvo et al. furthermore considered that HRQoL was of low priority as an endpoint and that measures created for lung cancer patients were underused.

Montazeri et al. identified the EORTC QLQ-C30 and the EORTC QLQ-LC13 as the most sophisticated questionnaires, compared to 50 other instruments to measure the HRQoL in lung cancer patients [55]. This might be one reason for their common use. Another might be the specific symptoms of the lung cancer disease. Moreover, the disease-specific, ordinal scaled profile instruments allow a separate evaluation of therapeutic effects for various dimensions. However, for the comparing of costs and effectiveness in health economic evaluations, an index value is required.

Many of the identified questionnaires allow for the aggregation into one index value, but this is by simply summarising the dimension values. Thus, it is based on an arbitrary weighting of individual aspects of quality of life. Such a value is met with the criticism of being barely interpretable and informative. In addition, the ordinal scaling of the items is inadequate for the economic 
evaluation of treatment alternatives. Here it is crucial, whether significant improvements in HRQoL can be achieved in the situation of relatively expensive therapy. The EQ-5D is the only identified questionnaire in this study that measures the quality of life in a cardinal index value and thus meets the requirements of cost-utility analyzes. However, as a generic instrument, the EQ-5D is limited by the disadvantage of a relatively low sensitivity in the measurement of small changes in quality of life. This is probably one reason for its relatively rare use in lung cancer studies.

Nevertheless, there are ways in which the identified questionnaires could be used in economic evaluations. One possibility is to transform the most widely used questionnaires EORTC QLQ-C30 and QLQ-LC13 into preference-based versions, similar to the development of the SF-36. This was already considered by the EORTC in the early 90s [50].

In what follows, we highlight some limitations with respect to our research strategy and the results of literature reviews in general. One major limitation of literature reviews is the publication bias. We only considered published full-text study results, no short reports, no conference presentations or study protocols. A comparison with the database clinicaltrials.gov might be a more complete research approach.

Furthermore the restriction of the publication time period might also be a limitation. However, we wanted to analyse the actual situation. In addition, the developments in the fields of HRQoL questionnaires could lead to problems of interpretation.

Our literature search was performed in the Pubmed database only. This is another limitation of our work. Nevertheless, we tried to limit this bias by conducting an additional manual search.

\section{Conclusions}

The cancer-specific EORTC QLQ-C30 with the lung cancer-specific LC13 module are the dominant instruments in HRQoL measurement in lung cancer studies. Besides these instruments, a broad spectrum of other questionnaires is used in different varieties and combinations. Only a small number of studies used generic instruments like the EQ-5D.

\section{Competing interests}

The authors declare that they have no competing interests.

\section{Authors' contributions}

$\mathrm{KD}$ and NR conducted the literature search. All authors reviewed the studies and wrote the manuscript. All authors read and approved the final manuscript.

\section{Author details}

${ }^{1}$ Center for Health Economics Research Hannover (CHERH), Leibniz University Hannover, Hannover, Germany. ${ }^{2}$ Herescon GmbH, Hannover, Germany.
Received: 4 February 2013 Accepted: 19 April 2013

Published: 16 May 2013

\section{References}

1. Robert Koch Institut: Gesellschaft der epidemiologischen Krebsregister in Deutschland e. V: Krebs in Deutschland 2005/2006. Berlin: Häufigkeiten und Trends; 2010.

2. Reck M: Quality of life as an endpoint of clinical trials. Lung Cancer 2009, 64(Suppl 1):22-23.

3. Liu J, Mittendorf T, von der Schulenburg JM: A structured review and guide through studies on health-related quality of life in kidney cancer, hepatocellular carcinoma, and leukemia. Cancer Invest 2010, 28:312-322.

4. Camps C, del Pozo N, Blasco A, Blasco P, Sirera R: Importance of quality of life in patients with Non-small-cell lung cancer. Clin Lung Cancer 2009, 10:83-90.

5. Schöffski O: Lebensqualität als Ergebnisparameter in gesundheitsökonomischen Studien. In Gesundheitsökonomische Evaluationen. Edited by Schöffski O, Von der Schulenburg JM. Berlin: Heidelberg: Springer; 2007:321-334.

6. Moher D, Liberati A, Tetzlaff J, Altman DG: Preferred reporting items for systematic reviews and meta-analyses: the PRISMA statement. BMJ 2009, 339:332-336.

7. Agteresch HJ, Rietveld T, Kerkhofs LG, van den Berg JW, Wilson JH, Dagnelie PC: Beneficial effects of adenosine triphosphate on nutritional status in advanced lung cancer patients: a randomized clinical trial. $J$ Clin Oncol 2002, 20:371-378.

8. Baka S, Ashcroft L, Anderson H, Lind M, Burt P, Stout R, Dowd I, Smith D, Lorigan $\mathrm{P}$, Thatcher N: Randomized phase II study of Two gemcitabine schedules for patients with impaired performance status (karnofsky performance status 70) and advanced Non-small-cell lung cancer. J Clin Oncol 2005, 23:2136-2144.

9. Belani CP, Pereira JR, von Pawel J, Pluzanska A, Gorbounova V, Kaukel E, Mattson KV, Ramlau R, Szczesna A, Fidias P, Millward M, Fossella F, TAX 326 study group: Effect of chemotherapy for advanced Non-small cell lung cancer on Patients' quality of life - a randomized controlled trial. Lung Cancer 2006, 53:231-239.

10. Bezjak A, Lee CW, Ding K, Brundage M, Winton T, Graham B, Whitehead M, Johnson DH, Livingston RB, Seymour L, Shepherd FA: Quality-of-life outcomes for adjuvant chemotherapy in early-stage Non-small-cell lung cancer: results from a randomized trial, JBR.10. J Clin Oncol 2008, 26:5052-5059.

11. Bezjak A, Tu D, Seymour L, Clark G, Trajkovic A, Zukin M, Ayoub J, Lago S, de Albuquerque Ribeiro R, Gerogianni A, Cyjon A, Noble J, Laberge F, Chan RT, Fenton D, Von Pawel J, Reck M, Shepherd FA, National Cancer Institute of Canada Clinical Trials Group Study BR.21: Symptom improvement in lung cancer patients treated with erlotinib: quality of life analysis of the national cancer institute of Canada clinical trials group study BR.21. J Clin Oncol 2006, 24:3831-3837.

12. Bianco V, Di Girolamo B, Pignatelli E, Speranza I, Florio G, Gemma D, Girolami M, Vietri F, Marchei P: Gemcitabine as single agent therapy in advanced Non small-cell lung cancer and quality of life in the elderly. Panminerva Med 2001, 43:15-19.

13. Booton R, Lorigan P, Anderson H, Baka S, Ashcroft L, Nicolson M, O'Brien M, Dunlop D, O'Byrne K, Laurence V, Snee M, Dark G, Thatcher N: A phase III trial of docetaxel/carboplatin versus mitomycin C/ifosfamide/cisplatin (MIC) or mitomycin C/vinblastine/cisplatin (MVP) in patients with advanced Nonsmall-cell lung cancer: a randomised multicenter trial of the british thoracic oncology group (BTOG1). Ann Oncol 2006, 17:1111-1119.

14. Bozcuk H, Dalmis B, Samur M, Ozdogan M, Artac M, Savas B: Quality of life in patients with advanced Non-small cell lung cancer. Cancer Nurs 2006 29:104-110.

15. Brown J, Thorpe H, Napp V, Fairlamb DJ, Gower NH, Milroy R, Parmar MK, Rudd RM, Spiro SG, Stephens RJ, Waller D, West P, Peake MD: Assessment of quality of life in the supportive care setting of the Big lung trial in Non-small-cell lung cancer. J Clin Oncol 2005, 23:7417-7424.

16. Cella D, Herbst RS, Lynch TJ, Prager D, Belani CP, Schiller JH, Heyes A, Ochs JS, Wolf MK, Kay AC, Kris MG, Natale RB: Clinically meaningful improvement in symptoms and quality of life for patients with Non-small-cell lung cancer receiving gefitinib in a randomized controlled trial. J Clin Oncol 2005, 23:2946-2954. 
17. Chen $M L$, Yu $C T$, Yang $C H$ : Sleep disturbances and quality of life in lung cancer patients undergoing chemotherapy. Lung Cancer 2008, 62:391-400

18. Dancey J, Shepherd FA, Gralla RJ, Kim YS: Quality of life assessment of second-line docetaxel versus best supportive care in patients with Non-small-cell lung cancer previously treated with platinum-based chemotherapy: results of a prospective, randomized phase III trial. Lung Cancer 2004, 43:183-194.

19. de Marinis F, Pereira JR, Fossella F, Perry MC, Reck M, Salzberg M, Jassem J, Peterson P, Liepa AM, Moore P, Gralla RJ: Lung cancer symptom scale outcomes in relation to standard efficacy measures - an analysis of the phase III study of pemetrexed versus docetaxel in advanced Non-small cell lung cancer. J Thorac Oncol 2008, 3:30-36.

20. Gelibter A, Ceribelli A, Pollera CF, Milella M, Moscetti L, Sperduti I, Cognetti F: Impact of gefitinib ('Iressa') treatment on the quality of life of patients with advanced non-small-cell lung cancer. J Cancer Res Clin Oncol 2005, 131:783-788.

21. Gridelli C, Gallo C, Shepherd FA, Illiano A, Piantedosi F, Robbiati SF, Manzione L, Barbera S, Frontini L, Veltri E, Findlay B, Cigolari S, Myers R, lanniello GP, Gebbia V, Gasparini G, Fava S, Hirsh V, Bezjak A, Seymour L, Perrone F: Gemcitabine plus vinorelbine compared with cisplatin plus vinorelbine or cisplatin plus gemcitabine for advanced Non-small cell lung cancer: a phase III trial of the Italian GEMVIN investigators and the national cancer institute of Canada clinical trials group. J Clin Oncol 2003, 21:3025-3034.

22. Grønberg BH, Bremnes RM, Fløtten O, Amundsen T, Brunsvig PF, Hjelde HH, Kaasa S, von Plessen C, Stornes F, Tollåli T, Wammer F, Aasebø U, Sundstrøm S: Phase III study by the Norwegian lung cancer study group: pemetrexed plus carboplatin compared with gemcitabine plus carboplatin as first-line chemotherapy in advanced Non-small-cell lung cancer. J Clin Oncol 2009, 27:3217-3224.

23. Helbekkmo N, Strøm HH, Sundstrøm SH, Aasebø U, Von Plessen C, Bremnes RM, Norwegian Lung Cancer Study Group: Chemotherapy and quality of life in NSCLC PS 2 patients. Acta Oncol 2009, 28:1019-1025.

24. Hensing TA, Peterman AH, Schell MJ, Lee JH, Socinski MA: The impact of Age on toxicity, response rate, quality of life, and survival in patients with advanced, stage IIIB or IV nonsmall cell lung carcinoma treated with carboplatin and paclitaxel. Cancer 2003, 98:779-788.

25. LeCaer H, Delhoume JY, Thomas PA, Berard H, Paillotin D, Barriere JR, Gimenez C, Vergnenegre A, Muller P, Auquier P, Perol M: Multicenter phase II trial of carboplatin/vinorelbine in elderly patients with advanced Non-small-cell lung cancer-efficacy and impact on quality of life: groupe français de pneumo-cancérologie study 9902. Clin Lung Cancer 2005, 7:114-120

26. Leighl NB, Paz-Ares L, Douillard JY, Peschel C, Arnold A, Depierre A, Santoro A, Betticher DC, Gatzemeier U, Jassem J, Crawford J, Tu D, Bezjak A, Humphrey JS, Voi M, Galbraith S, Hann K, Seymour L, Shepherd FA: Randomized phase III study of matrix metalloproteinase inhibitor BMS-275291 in combination with paclitaxel and carboplatin in advanced Non-small-cell lung cancer: national cancer institute of Canada-clinical trials group study BR.18. J Clin Oncol 2005, 23:2831-2839.

27. Lilenbaum R, Axelrod R, Thomas S, Dowlati A, Seigel L, Albert D, Witt K, Botkin D: Randomized phase II trial of erlotinib or standard chemotherapy in patients with advanced non-small-cell lung cancer and a performance status of 2. J Clin Oncol 2008, 26:863-869.

28. Maione P, Perrone F, Gallo C, Manzione L, Piantedosi F, Barbera S, Cigolari S, Rosetti F, Piazza E, Robbiati SF, Bertetto O, Novello S, Migliorino MR, Favaretto A, Spatafora M, Ferraù F, Frontini L, Bearz A, Repetto L, Gridelli C, Barletta E, Barzelloni ML, laffaioli RV, De Maio E, Di Maio M, De Feo G, Sigoriello G, Chiodini P, Cioffi A, Guardasole V, et al: Pretreatment quality of life and functional status assessment significantly predict survival of elderly patients with advanced Non-small-cell lung cancer receiving chemotherapy: a prognostic analysis of the multicenter Italian lung cancer in the elderly study. J Clin Oncol 2005, 23:6865-6872.

29. McQuellon RP, Moose DB, Russell GB, Case LD, Greven K, Stevens M, Shaw EG: Supportive Use of magestrol acetate (megace) with head/neck and lung cancer patients receiving radiation therapy. Int $J$ Radiat Oncol Biol Phys 2002, 52:1180-1185.

30. Mohan A, Singh P, Kumar S, Mohan C, Pathak AK, Pandey RM, Guleria R: Effect of change in symptoms, respiratory status, nutritional profile and quality of life on response to treatment for advanced Non-small cell lung cancer. Asian Pac J Cancer Prev 2008, 9:557-562.
31. Moinpour CM, Lyons B, Grevstad PK, Lovato LC, Crowley J, Czaplicki K, Buckner ZM, Ganz PA, Kelly K, Gandara DR: Quality of life in advanced Non-small-cell lung cancer: results of a southwest oncology group randomized trial. Qual Life Res 2002, 11:115-126.

32. Morita S, Kobayashi K, Eguchi K, Matsumoto T, Shibuya M, Yamaji Y, Sakamoto J, Ohashi Y: Influence of clinical parameters on quality of life during chemotherapy in patients with advanced Non-small cell lung cancer: application of a general linear model. Jpn J Clin Oncol 2003, 33:470-476.

33. Movsas B, Scott C, Langer C, Werner-Wasik M, Nicolaou N, Komaki R, Machtay M, Smith C, Axelrod R, Sarna L, Wasserman T, Byhardt R: Randomized trial of amifostine in locally advanced Non-small-cell lung cancer patients receiving chemotherapy and hyperfractionated radiation: radiation therapy oncology group trial 98-01. J Clin Oncol 2005, 23:2145-2154.

34. Mu XL, Li LY, Zhang XT, Wang SL, Wang MZ: Evaluation of safety and efficacy of gefitinib ('iressa', zd1839) as monotherapy in a series of Chinese patients with advanced non-small-cell lung cancer: experience from a compassionate-use programme. BMC Cancer 2004, $4: 1-8$.

35. Natale RB: Effects of ZD1839 (iressa, gefitinib) treatment on symptoms and quality of life in patients with advanced Non-small cell lung cancer. Semin Oncol 2004, 31:23-30.

36. O'Brien ME, Ciuleanu TE, Tsekov H, Shparyk Y, Cuceviá B, Juhasz G, Thatcher $\mathrm{N}$, Ross GA, Dane GC, Crofts T: Phase III trial comparing supportive care alone with supportive care with oral topotecan in patients with relapsed small-cell lung cancer. J Clin Oncol 2006, 24:5441-5447.

37. Paccagnella A, Favaretto A, Oniga F, Barbieri F, Ceresoli G, Torri W, Villa E, Verusio C, Cetto GL, Santo A, De Pangher V, Artioli F, Cacciani GC, Parodi G, Soresi F, Ghi MG, Morabito A, Biason R, Giusto M, Mosconi P, Chiarion Sileni V, GSTVP (Gruppo di Studio Tumori Polmonari del Veneto): Cisplatin versus carboplatin in combination with mitomycin and vinblastine in advanced Non-small cell lung cancer. A multicenter, randomized phase III trial. Lung Cancer 2004, 43:83-91.

38. Pijls-Johannesma M, Houben R, Boersma L: High-dose radiotherapy or concurrent chemo-radiation in lung cancer patients only induces a temporary, reversible decline in QoL. Radiother Oncol 2009, 91:443-448.

39. Reck M, von Pawel J, Macha HN, Kaukel E, Deppermann KM, Bonnet R, Ulm K, Hessler S, Gatzemeier U: Efficient palliation in patients with small-cell lung cancer by a combination of paclitaxel, etoposide and carboplatin: quality of life and 6-Years'-follow-Up results from a randomised phase III trial. Lung Cancer 2006, 53:67-75.

40. Sarna L, Swann S, Langer C: Clinically meaningful differences in patientreported outcomes with amifostine in combination with chemoradiation for locally advanced Non-small cell lung cancer: an analysis of RTOG 9801. Int J Radiat Oncol Biol Phys 2008, 72:1378-1384

41. Schumacher A, Riesenbeck D, Braunheim M, Wewers D, Heinecke A, Semik M, Hoffknecht P, Macha HN, Klinke F, Schmidt EW, Willich N, Berdel WE, Thomas M, German Lung Cancer Cooperative Group: Combined modality treatment for locally advanced Non-small cell lung cancer: preoperative chemoradiation does Not result in a poorer quality of life. Lung Cancer 2004, 44:89-97.

42. Sekine I, Ichinose Y, Nishiwaki Y, Yamamoto N, Tsuboi M, Nakagawa K, Shinkai T, Negoro S, Imamura F, Eguchi K, Takeda K, Itoh Y, Tamura T, Saijo N, Fukuoka M: Quality of life and disease-related symptoms in previously treated Japanese patients with Non-small cell lung cancer: results of a randomized phase III study (V-15-32) of gefitinib versus docetaxel. Ann Oncol 2009, 20:1483-1488.

43. Sirisinha T, Sirilertrakul S, Jirajarus M, Ratanatharathorn V: Doxetaxel in previously treated Non-small cell lung cancer patients: clinical efficacy and quality of life. Southeast Asian J Trop Med Public Health 2005, 36:246-253.

44. Thatcher N, Qian W, Clark PI, Hopwood P, Sambrook RJ, Owens R, Stephens RJ, Girling DJ: Ifosfamide, carboplatin, and etoposide with midcycle vincristine versus standard chemotherapy in patients with small-cell lung cancer and good performance status: clinical and quality-of-life results of the British medical research council multicenter randomized LU21 trial. J Clin Oncol 2005, 23:8371-8379.

45. Tian JH, Liu LS, Shi ZM, Zhou ZY, Wang L: A randomized controlled pilot trial of "feiji recipe" on quality of life of Non-small cell lung cancer patients. Am J Chin Med 2010, 38:15-25. 
46. Vilmar A, Santoni-Rugiu E, Sørensen JB: ERCC1, Toxicity and quality of life in advanced NSCLC patients randomized in a large multicentre phase III trial. Eur J Cancer 2010, 46:1554-1562.

47. Von Plessen C, Bergman B, Andresen O, Bremnes RM, Sundstrom S, Gilleryd M, Stephens R, Vilsvik J, Aasebo U, Sorenson S: Palliative chemotherapy beyond three courses conveys No survival or consistent quality-of-life benefits in advanced Non-small cell lung cancer. Br J Cancer 2006, 95:966-973.

48. Wu WY, Long SQ, Zhang HB, Chai XS, Deng H, Xue XG, Wang B, Luo HY, Liu WS: Improvement of quality of life with shenfu injection in Non small-cell lung cancer patients treated with gemcitabine plus cisplatin regimen. Chin J Integr Med 2006, 12:50-54.

49. Zhang XT, Li LY, Wang SL, Mu XL, Wang MZ, Song W: Improvements in quality of life and disease-related symptoms in patients with advanced Non-small cell lung cancer treated with gefitinib. Chin Med J 2005, 118:1661-1664.

50. Aaronson NK, Ahmedzai S, Bergman B, Bullinger M, Cull A, Duez NJ, Filiberti A, Flechtner H, Fleishman SB, de Haes JC, Stein Kaasa S, Klee M, Osoba D, Razavi D, Rofe PB, Schraub S, Sneeuw K, Sullivan M, Takeda F: The European organization for research and treatment of cancer QLQ-C30: a quality-oflife instrument for use in international clinical trials in oncology. J Natl Cancer Inst 1993, 85:365-376.

51. Cella DF, Tulsky DS, Gray G, Sarafian B, Linn E, Bonomi A, Silberman M, Yellen SB, Winicour P, Brannon J: The functional assessment of cancer therapy scale: development and validation of the general measure. J Clin Oncol 1993, 11:570-579.

52. PROQOLID - Patient-Reported Outcome and Quality of life Instruments Database. http://www.proqolid.org/.

53. Damm K, Jacob C, Mittendorf T, von der Schulenburg JM: Lebensqualitätsmessung in klinischen Studien beim Lungenkarzinom Übersicht anhand der Datenbank ClinicalTrials.gov [Measuring Health Related Quality of Life in Lung Cancer Clinical Trials - An Overview of the Database ClinicalTrials.gov]. PharmacoEconomics - German Research Articles 2012, 10:3-15.

54. Salvo N, Hadi S, Napolskikh J, Goh P, Sinclair E, Chow E: Quality of life measurement in cancer patients recieving palliative radiotherapy for symptomatic lung cancer: a literature review. Current Oncology 2009, 16:16-28.

55. Montazeri A, Gillis CR, McEwen J: Quality of life in patients with lung cancer: a review of literature from 1970 to 1995 . Chest 1998, 113:467-481.

doi:10.1186/2191-1991-3-15

Cite this article as: Damm et al:: Health-related quality of life questionnaires in lung cancer trials: a systematic literature review. Health Economics Review 2013 3:15.

\section{Submit your manuscript to a SpringerOpen ${ }^{\circ}$ journal and benefit from:}

- Convenient online submission

- Rigorous peer review

- Immediate publication on acceptance

- Open access: articles freely available online

- High visibility within the field

- Retaining the copyright to your article

Submit your next manuscript at $\gg$ springeropen.com 